\title{
The Qualities of Effective Teachers as Perceived by Saudi EFL Students and Teachers
}

\author{
Iman Alzobiani ${ }^{1}$ \\ ${ }^{1}$ Taibah University, Madinah, Saudi Arabia \\ Correspondence: Iman Alzobiani, Taibah University, Madinah, Saudi Arabia \\ Received: December 14, 2019 \\ Accepted: January 7, 2020 \\ Online Published: January 8, 2020 \\ doi: $10.5539 /$ elt.v13n2p32 \\ URL: https://doi.org/10.5539/elt.v13n2p32
}

\begin{abstract}
The aim of this study was to investigate the dominant types of qualities of effective teachers. The study further aimed at exploring the extent to which the students' and teachers' perceptions are different. The sample of the current study consisted of 150 students and 40 teachers in (16) female public intermediate schools in Al-Madinah Al-Munawarah to participate in the study. To achieve the purpose of the study, data were collected via a four point Likert-scale questionnaire designed by the researcher. The results of the descriptive statistics indicated that the mean and rank of the two types of the qualities of effective EFL teachers revealed that the dominant type among the participants was the instructional skills. Meanwhile, the personal traits of effective EFL teachers were ranked first by teachers and second by students. Additionally, the results of the Independent Sample T-Test showed no statically significant differences in the perceptions of Saudi EFL students and teachers with respect to the qualities of effective teachers.
\end{abstract}

Keywords: qualities of Effective EFL teachers, EFL teachers, effective teachers, personal traits, instructional Skills

\section{Introduction}

Teacher effectiveness has been an ongoing topic of interest amongst educational researchers for several years, with substantial focus given to personal traits and instructional skills that are believed to characterize effective teachers. Hativa Barak, and Simhi (2001) pointed out that teacher effectiveness is not only about fitting a particular teacher type or following a set of designed criteria but also involves understanding what it really means to be an effective teacher and implementing classroom practices that are appropriate for the wider teacher context.

Effective teaching is of great significance for efficient functioning of educational systems and for improving the quality of learning. Research supports the notion that an effective teacher's actions play an essential role in provoking effective and efficient learning on the part of the learners. Shishavan and Sadeghi (2009) argue that teachers have a fundamental role in their learners' academic achievement and that their effectiveness can highly influence learners' outcomes. It is widely acknowledged that the most effective way to improve student learning outcomes is the quality of teaching, paying huge attention to teachers' ability to motivate, and facilitative learning.

English language teachers are by no means an exemption and their vital role in effective language learning cannot be negotiated. Although effective teachers in general may share some characteristics, there are certain qualities that are different among them depending on the subject they teach. Brown (2009) points out that foreign language learning not only include the transmission of concepts and facts but also, in many cases, through the subject under examination.

An effective EFL teacher should possess a wide range of qualities which will be classified in the current study into: personal traits and instructional skills. As stated by Brown (2009), good personal traits and instructional skills are equally important as they play a major role in the effectiveness of learning. Although the two dimensions mentioned above are essential for effective teaching, a distinction must be made between personal traits and instructional skills that best describe an effective teacher. Research on teachers' effectiveness highlights personal traits such as patience (Khodabakhshzadeh \& Shirvan, 2011; Sadeghi \& Babai, 2009), friendliness (Al-Maqtri\& Thabet, 2013; Sadeghi\& Babai, 2009), enthusiasm (Malikow, 2005; Witcher, 2003), 
interest in their career (Malikow, 2005; Rubio, 2009), interest in their students (Borg, 2006), sense of humor (Lee, 2010; Saafin, 2005), confidence (Wheeler \& Mcleod, 2002), cooperation (Malikow, 2005; Stronge, 2007), motivation (Malikow, 2005; Rubio, 2009), caring (Chen \& Lin, 2009; Gao \& Liu, 2013), flexibility (Wheeler \& Mcleod, 2002), and understanding (Slate, 2009).

Effective teachers' instructional skills are not just a series of techniques that teachers need to be familiarized with and then use automatically in class. Liakopoulou (2011) states that they are a set of skills that teachers need to acquire in order to save time and energy, and achieve better outcomes. It has been indicated by Anderson (2004) and Jasman (2003) that effective teachers should possess skills such as applying various teaching methods, presenting information clearly, using a variety of teaching aids, promoting students' interest, providing constructive feedback, recognizing students' individual differences, and building their teaching based on their needs. Stronge (2004) indicate that instructional skills are classified into a number of sub-skills under four main dimensions: classroom supervision and organization, arranging for instruction, executing instruction and observing student progress and potential.

To sum up, becoming an effective EFL teacher involves developing and integrating instructional, interpersonal, and intrapersonal skills in ways that allow them to structure the physical, social, and intellectual environment of the classrooms. Effective EFL teachers are aware that students need to learn more than the subject matter in order to be ready for using the language beyond the classroom.

Teachers play a key role in improving their own profession. Teachers are the link between theory and practice. It is indicated by Khodabakhshzadeh and Shirvan (2011) that teachers are not just the receivers of a load of theories and knowledge from teachers' educators and follow a routine like approach in their classroom but rather they are "theorizers of their own practice and practitioners of their own theories". Mullock (2003) states that teacher's beliefs, perceptions and assumptions about teaching and teacher efficacy affect the way instruction is organized and understood. Since perception is the best indicator of the decisions an individual make throughout life, Williams and Burden (1997) highlight the close relationship between beliefs and actions amongst teachers and students. They claimed that "teachers' actions are highly influenced by their beliefs and stated that their beliefs will affect their actions in the classroom" (pp. 48-49). Studying the perceptions of learners about learning and teaching is of equal importance to the ones of teachers as Lee (2010) assures. Their beliefs about language learning seem to have obvious relation to understanding their "expectations of the course, their commitment to the class as well as providing them with the opportunity to be successful and satisfied" with their language learning program (Al-Maqtri \& Thabet, 2013). Moreover, investigating students' beliefs about different behaviors in the language classroom is useful in informing teachers about different types of learners that need to be took care of.

\section{Definitions of Terms}

\subsection{An Effective Teacher}

Chen and Lin (2009) state that an effective EFL teacher is not only one who is academically qualified and knows one's subject matter well, but also "one who is capable of tailoring one's material to suit student needs"; thus motivating them to learn besides being "capable of bonding well with students, and consequently respecting each other".

Stronge (2007) offered a generalized definition of an effective teacher as the one who owns a collection of characteristics, competencies, and behaviors at all educational levels that enable students to reach desired outcomes, which may include the attainment of specific learning objectives as well as broader goals such as being able to solve problems, think critically, work collaboratively, and become effective learner.

Operationally, effective teachers in the current study are those who adopt instructional skills and personal traits that contribute to effective language teaching.

\subsection{The Qualities of Effective Teachers}

Liakopoulou (2011) defines the qualities of effective teachers as "the individual qualifications and attitudes of teachers, as well as their skills and knowledge" (p. 66).

Mackinnon (2007) refers the qualities of an effective teacher to "the characteristics that teachers possess which make their teaching ability effective towards students' learning" (p. 11).

In the present study, the qualities that are deemed significant to being an effective teacher are the instructional skills and personal traits that intermediate students and teachers perceive to form an effective EFL teacher. 


\subsection{Personal Traits}

Wang et al, (2007) state that personal traits encompass human characteristics related to the professional role of a teacher which can be nurtured and developed through initial education and continuous training.

Operationally, personal traits are classified into two main dimensions: interpersonal traits and intrapersonal traits. Interpersonal traits involve the interpretation of social interactions with others. The combination of various skills are listening, communicating, discerning, and interpreting. Intrapersonal traits indicate teachers' cognitive ability to understand and sense themselves such as self-esteem, self-enhancement, and strength of character. These dimensions highlight the significance of the human element in the teaching and learning process reflected through the respondents' perceptions.

\subsection{Instructional Skills}

Instructional skill is defined by Chen (2012) as the most specific category of teaching behaviors. They are necessary for procedural purposes and for structuring appropriate learning experiences for students.

In the current study, instructional skills consist of four main dimensions: planning instruction, implementing instruction, monitoring students' progress and potential, and classroom management and organization that the respondents consider to form an effective teacher.

\section{Statement of the Problem}

Teaching English in Saudi Arabia is primarily teacher-centered. Language learning happens mainly in formal classroom settings. Teachers represent the main source of language input. Consequently, special attention must be paid to the relationship between students and teachers.

Bell (2005) shed light on the fact that a study focusing on comparing and contrasting the perceptions of student and teacher would be another step in explaining effective EFL teaching behaviors. Teachers and their students may have similar or different concepts of effective teaching, and the intersection of the two systems has ramifications for students' language learning and the efficacy of instruction (Brown, 2009).

Though limited, the research available on EFL teacher qualities has focused primarily on how they characterize themselves. Most existing studies have not included the voices of one of the biggest stakeholders in English language teaching i.e. the students (Lee, 2010). Relatively, few studies have specifically compared and contrasted individual teacher's perceptions of effective teaching practices with those of the students (Park \& Lee, 2006; Brown, 2009; Shishvan \& Sadeghi, 2009; Chen \& Lin, 2009). Those studies suggested that students and teachers may hold diverse insights with respect to the qualities of an effective EFL teacher.Therefore, the present study was an attempt to investigate the qualities of an EFL teacher as perceived by Saudi students and teachers at the intermediate level. Bridging the gap between students and teachers in an EFL classroom was the ultimate goal of the process of comparing and contrasting that takes place in this study.

\section{Purposes of the Study}

This study attempts to:

1. Explore the dominant qualities of an effective teacher as perceived by Saudi EFL students and teachers at the intermediate level.

2. Explore the extent of differences in perceptions between Saudi EFL students and teachers with respect to the qualities of effective teachers.

\section{Questions of the Study}

Based upon the above mentioned purposes, the current study attempts to answer these questions:

1. What are the dominant qualities of an effective teacher as perceived by Saudi EFL students and teachers at the intermediate level?

2. To what extent are Saudi EFL students' and teachers' perceptions of the qualities of effective teachers different?

\section{Significance of the Study}

The findings of the current study are of a great significant both practically and theoretically:

1. The recording of teachers' and students' perceptions may, to some degree, ensure that the study programs for initial training are designed according to the needs of the Saudi EFL teachers and learners. 
2. Taking into consideration EFL teachers' and students' specific needs with reference to Saudi context, assist administrators and educational policy makers in Saudi Arabia in making decisions concerning curriculum design and in-service training programs.

3. The findings of the study form the basis for creating a system of assessment criteria, a framework for the evaluation and self-assessment, and predicting effective Saudi EFL teachers' decisions.

4. Investigating students' and teachers' perceptions help teachers in understanding themselves and their students' expectations which consequently can influence their professional growth, efficacy, ability to deal with changes in education, making innovations in their practice and creating an emotionally positive and academically productive atmosphere in the classroom.

\section{Delimitations of the Study}

This study was delimited to:

1. Saudi Female EFL students and teachers in the intermediate public schools in Al- Madinah Al-Munawarah.

2. Intrapersonal and Interpersonal traits of effective teachers.

3. The following instructional skills of effective teachers: planning for instruction, implementing instruction, monitoring students' progress, and classroom management.

\section{Design of the Study}

This study is descriptive and analytic with an intention to identify the qualities of effective EFL teachers, specify the dominant personal traits and instructional skills of effective teachers, and highlight the differences in perceptions between Saudi EFL students and teachers with respect to the qualities of effective teachers.

\subsection{Population and Sample of the Study}

The population of the study involved EFL students and teachers enrolled in the public intermediate schools in Al-Madinah Al-Munawarah. The sample of the study was chosen using random stratified sampling technique. The sample of the current study consisted of 150 students and 40 teachers.

\subsection{Data Collection Instrument}

The instrument of any research is usually determined by the nature of the research and its objectives. Therefore, it is very important to use an appropriate tool in order to achieve the intended objectives. As the current study aims at investigating the dominant types of qualities of effective teachers as perceived by Saudi EFL students and teachers, the researcher finds that an instrument in a form of a questionnaire would be appropriate to collect the data required to achieve the objectives of the current study.

\subsubsection{Constructing the Questionnaire}

A wide careful survey was made of literature on the qualities of effective EFL teachers which provided the framework that served as guide in specifying the questionnaire dimensions and writing the statements of the questionnaire. Moreover, the researcher reviewed statements encountered in previous studies that dealt with the qualities of effective EFL teachers. Consequently, the questionnaire statements were formed according to the dimensions in a way that match the study sample characteristics. Furthermore, the questionnaire is developed in English for EFL teachers. An Arabic version of the questionnaire is administrated to EFL students to facilitate their participation in answering the questionnaire statements. Participants were asked to report their perceptions about the qualities of effective EFL teachers on a 4-point Likert scale, by indicating the degree of agreement on each statement ( $4=$ strongly disagree, $3=$ disagree, $2=$ agree, $1=$ strongly agree).

The items of the questionnaire were divided into two major dimensions: personal traits and instructional skills of effective EFL teachers.

* The first section is intended to collect students' and teachers' perception regarding the personal traits of effective EFL teachers. Two sub-dimensions are contained: interpersonal traits and intrapersonal traits.

* The second section is designed to investigate students' and teachers' perception about the instructional skills of effective EFL teachers. Four sub-dimensions are included: planning instruction, implementing instruction, monitoring students' progress, and classroom management.

The first draft of the questionnaire consisted of 64 items: 18 items on personal traits and 46 on instructional skills. Some items were deleted, others were reworded. 
The second draft of the questionnaire was developed after required modification was done containing 58 statements in both English and Arabic versions. The section on effective EFL teachers' personal traits consisted of 17 items and the part on effective EFL teachers' instructional skills embodied 41 items.

\subsubsection{Validity of the Questionnaire}

The second draft of the questionnaire was presented to a panel of experts in the English language curriculum and instruction in different universities in Saudi Arabia with Arabic as their native language. The jury members suggested some modifications to a number of items. Items 5, 6, 8, 43, 49 in the Arabic version were reworded. Statements under "planning instruction" were modified to be more related to the sub-dimensions and some items were deleted.

\subsubsection{Piloting of the Questionnaire}

The purposes of conducting the pilot study are to ensure the clarity of statements, and to determine the reliability of the questionnaire. The pilot study was conducted at the $65^{\text {th }}$ intermediate school in Al-Madinah Al-Munawarah. The piloting group consisted of students $(n=15)$ randomly chosen from the three intermediate grade levels and EFL teachers $(n=3)$. The participants were encouraged to identify any unclear statements and state any difficulty they face while responding to the items. It has been indicated by the participants that no ambiguity or difficulty was faced during the process of answering the questionnaire.

\subsubsection{Reliability of the Questionnaire}

To measure the reliability the questionnaire, the researcher used Cronbach's alpha. This method examined the internal consistency of the items in the scale utilizing the data collected in the pilot study.

As shown in Table (1), the internal consistency of the personal traits (16 items) was 0.83 and the internal consistency of the instructional skills (37 items) was 0.92 reflecting a high level of internal consistency in both dimensions. Furthermore, the overall statements were tested and the results revealed a reliability coefficient of 0.94 indicating a high level of internal consistency. Therefore, the questionnaire can be considered as a reliable data collection tool for the purposes of this study.

Table 1. Cronbach's alpha coefficients for the questionnaire

\begin{tabular}{ccc}
\hline Items & $\begin{array}{c}\text { Number } \\
\text { of Items }\end{array}$ & $\begin{array}{c}\text { Cronbach's } \\
\text { Alpha }\end{array}$ \\
\hline $\begin{array}{c}\text { The } \\
\text { personal } \\
\text { qualities of } \\
\text { effective } \\
\text { EFL }\end{array}$ & 16 & 0.83 \\
teachers & & \\
$\quad$ The & 37 & 0.92 \\
$\begin{array}{c}\text { instructional } \\
\text { qualities of } \\
\text { effective } \\
\text { EFL }\end{array}$ & & \\
teachers & & \\
Overall \\
qualities of \\
effective \\
EFL \\
teachers
\end{tabular}

\subsubsection{Final form of the Questionnaire}

The final form of the questionnaire consists of 53 items divided into two main sections:

* The personal traits of effective EFL teachers contained 16 items divided into: interpersonal traits $(9$ items) and intrapersonal traits (7 items).

* The instructional skills of effective EFL teachers consisted of 37 items comprising of four sub-dimensions: planning instruction (13 items), implementing instruction (7 items), monitoring students' progress (8 items), and classroom management (9 items). 


\subsection{Data Collection}

Data collection took place over a month period during the first semester of the academic year 1435/36 H - 2014

A. D. In order to collect the required data for the current study, the following procedures were carried out:

1. Prior to the questionnaires being distributed, a permission to conduct the study in the public schools in Al-Madinah Al-Munawarah is needed.

2. Once permission was obtained, the researcher divided the public intermediate schools in Al-Madinah Al-Munawarah according to their geographical location: northern, southern, eastern, western.

3. Based on the geographical location four schools were selected randomly with a total of sixteen intermediate schools in Al-Madinah Al-Munawarah.

4. Ten students from each school were selected randomly from the three intermediate grade levels $(n=160)$ and all the EFL teachers in the sixteen selected schools $(n=44)$ to participate in the data collection.

5. The researcher distributed printed copies of the questionnaire package through personal visits to the sample schools.

6. Arabic version of the questionnaire is used to collect students' perceptions to ensure understanding of the statements and the English version to investigate teachers' perceptions.

\subsection{Data Analysis}

The following statistical techniques were used to analyze the collected data and for testing the hypotheses of the study:

- The dominant qualities of effective teachers as perceived by Saudi EFL students and teachers were determined by the ranking of the mean scores.

- Independent Samples t-test was conducted to find the significant difference between students' and teachers' perceptions.

\section{Results and Discussion}

\subsection{Results Concerning the Dominant Qualities of Effective EFL Teachers}

To answer the study question "What are the dominant qualities of an effective teacher as perceived by Saudi EFL students and teachers at the intermediate level?", the mean scores and the standard deviations of each dimension of the questionnaire were computed in order to identify the most dominant type of the qualities of effective EFL teachers. Table 2, shows the details of the mean scores and standard deviations for each dimension and domain of the personal traits and the instructional skills of an effective EFL teacher.

Table 2. Mean scores and standard deviations for each dimension and domain of the personal traits and the instructional skills of an effective EFL teacher

\begin{tabular}{|c|c|c|c|c|c|c|c|c|c|c|}
\hline \multirow[t]{2}{*}{ Dimension } & \multirow[t]{2}{*}{ Domain } & \multicolumn{3}{|c|}{ Students } & \multicolumn{3}{|c|}{ Teachers } & \multicolumn{3}{|c|}{ All Participants } \\
\hline & & Mean & S.D & Rank & Mean & S.D & Rank & Mean & S.D & Rank \\
\hline \multirow[t]{3}{*}{ Personal Traits } & Interpersonal Traits & 3.17 & 0.39 & 1 & 3.39 & 0.48 & 1 & 3.24 & 0.55 & 1 \\
\hline & Intrapersonal Traits & 3.08 & 0.43 & 2 & 3.39 & 0.46 & 1 & 3.14 & 0.55 & 2 \\
\hline & Total Mean & 3.13 & 0.36 & - & 3.39 & 0.44 & - & 3.20 & 0.24 & - \\
\hline \multirow{5}{*}{$\begin{array}{l}\text { Instructional } \\
\text { Skills }\end{array}$} & Planning instruction & 3.42 & 0.46 & 1 & 3.30 & 0.39 & 1 & 3.42 & 0.13 & 1 \\
\hline & $\begin{array}{l}\text { Implementing } \\
\text { instruction }\end{array}$ & 3.37 & 0.44 & 2 & 3.21 & 0.39 & 3 & 3.34 & 0.11 & 2 \\
\hline & $\begin{array}{c}\text { Monitoring students' } \\
\text { Progress }\end{array}$ & 3.32 & 0.49 & 3 & 3.15 & 0.33 & 4 & 3.07 & 0.22 & 3 \\
\hline & $\begin{array}{c}\text { Classroom } \\
\text { Management }\end{array}$ & 3.29 & 0.49 & 4 & 3.26 & 0.38 & 2 & 2.96 & 0.16 & 4 \\
\hline & Total Mean & 3.35 & 0.39 & - & 3.24 & 0.30 & - & 3.22 & 0.53 & - \\
\hline \multicolumn{2}{|c|}{ Total Mean of Whole Instrument } & 3.29 & 0.36 & - & 3.28 & 0.33 & - & 3.21 & 0.35 & - \\
\hline
\end{tabular}

Table 2 shows that the total mean of the sample's responses on the whole instrument is (3.21), whereas the total mean of the students' and teachers' responses of the whole instrument is (3.29) and (3.28) respectively indicating 
the degree of agreement relating to students' and teachers' perceptions for all different types of qualities of effective EFL teachers is "agree".

Furthermore, the dimension of the "Personal Traits" of effective EFL teachers is ranked second by the sample ( $M$ $=3.20)$. Specifically, it is ranked second by students $(M=3.13)$ and first by teachers $(M=3.39)$. On the other hand, the dimension of the "Instructional Skills" of effective EFL teachers is ranked first by the sample $(M=$ 3.22). However, the skill of the "Instructional Skills" is ranked first by students $(M=3.35)$ and second by teachers $(M=3.24)$.

Moreover, the skill of the "Interpersonal Traits" of effective EFL teachers is ranked first by the sample $(M=$ 3.24). Specifically it is ranked first by students and teachers $(M=3.17$ and 3.39) respectively. On the other hand, the skill of the "Intrapersonal Traits" of effective EFL teachers is ranked second by the sample $(M=3.14)$. However, the skill of the "Intrapersonal Traits" is ranked second by students $(M=3.08)$ and first by teachers $(M$ $=3.39$ ).

Additionally, the skill of "Planning instruction" of effective EFL teachers is ranked first by all sample $(M=3.42)$. Specifically it is ranked first by students and teachers $(M=3.42$ and 3.30) respectively. Moreover, the skill of "Implementing instruction" of effective EFL teachers is ranked second by the sample $(M=3.34)$. Particularly it is ranked second by students $(M=3.37)$ and third by teachers $(M=3.21)$. Additionally, the skill of "Monitoring students' Progress" of effective EFL teachers is ranked third by the sample $(M=3.07)$. Specifically it is ranked third by students $(M=3.32)$ and fourth by teachers $(M=3.15)$. Furthermore, the skill of "Classroom Management" of effective EFL teachers is ranked fourth by the sample $(M=2.96)$. In particular, it is ranked fourth by students $(M=3.29)$ and second by teachers $(M=3.26)$.

It can be stated that the interpersonal traits are ranked first and then followed by the intrapersonal traits. While teachers ranked both the interpersonal and intrapersonal traits at the same level. These results are due to the fact that students give significant importance to being safe in their environment, whereas teachers establish a democratic environment that fosters positive student-teacher relationships.

Also, it can be stated that planning instruction is ranked as the most dominant skill by both students and teachers. These results are due to the fact that planning instruction helps the teachers focus on the lesson objectives; review the subject matter and available resources before presenting it to students; and consequently decide how to introduce, deliver and assess. Moreover, implementing instruction is considered as the second and third dominant skill by students and teachers respectively. Additionally, monitoring students' progress is placed third and fourth by students and teachers respectively. Similarly, monitoring students' progress was placed as the last priority by Shahini and Daftarifard (2011). While classroom management comes in the fourth rank according to students, it is ranked as the second dominant skill among the instructional skills of effective EFL teachers.

\subsection{Results Concerning the Dominant Personal Traits of Effective EFL Teachers}

To answer the study question "What are the dominant personal traits of an effective teacher as perceived by Saudi EFL students and teachers at the intermediate level?", the mean scores, standard deviations and the rank order of each criterion of the personal traits were calculated in order to identify the most dominant traits. As depicted in Table 3. 
Table 3. Descriptive statistics and rank order of each criterion of the personal traits of an effective EFL teacher

\begin{tabular}{|c|c|c|c|c|c|c|c|c|c|c|}
\hline \multirow[t]{2}{*}{ No. } & \multirow[t]{2}{*}{ Item } & \multicolumn{3}{|c|}{ Students } & \multicolumn{3}{|c|}{ Teachers } & \multicolumn{3}{|c|}{ All Participants } \\
\hline & & Mean & S.D & Rank & Mean & S.D & Rank & Mean & S.D & Rank \\
\hline 1 & $\begin{array}{l}\text { Avoiding } \\
\text { student } \\
\text { favoritism }\end{array}$ & 3.14 & 1.04 & 13 & 3.00 & 0.99 & 16 & 3.11 & 1.03 & 14 \\
\hline 2 & $\begin{array}{l}\text { Displaying } \\
\text { friendly } \\
\text { attitude }\end{array}$ & 3.55 & 0.63 & 3 & 3.32 & 0.73 & 13 & 3.50 & 0.66 & 5 \\
\hline 3 & $\begin{array}{l}\text { Having sense } \\
\text { of humor }\end{array}$ & 3.19 & 0.73 & 12 & 3.37 & 0.49 & 11 & 3.23 & 0.69 & 12 \\
\hline 4 & Flexibility & 3.19 & 0.82 & 11 & 3.42 & 0.75 & 8 & 3.24 & 0.81 & 11 \\
\hline 5 & Caring & 3.50 & 0.76 & 6 & 3.42 & 0.75 & 7 & 3.48 & 0.75 & 7 \\
\hline 6 & $\begin{array}{l}\text { Maintaining a } \\
\text { good } \\
\text { teacher-student } \\
\text { relationship }\end{array}$ & 3.57 & 0.72 & 2 & 3.32 & 0.73 & 12 & 3.51 & 0.72 & 4 \\
\hline 7 & $\begin{array}{l}\text { Treating } \\
\text { students with } \\
\text { respect }\end{array}$ & 1.40 & 0.68 & 16 & 3.57 & 0.63 & 2 & 1.86 & 1.11 & 16 \\
\hline 8 & $\begin{array}{l}\text { Understanding } \\
\text { of others }\end{array}$ & 3.45 & 0.85 & 7 & 3.45 & 0.68 & 6 & 3.66 & 2.98 & 1 \\
\hline 9 & $\begin{array}{l}\text { Showing a } \\
\text { good moral } \\
\text { character }\end{array}$ & 3.57 & 0.65 & 1 & 3.62 & 0.74 & 1 & 3.58 & 0.67 & 2 \\
\hline 10 & $\begin{array}{l}\text { Being well } \\
\text { organized in } \\
\text { appearance }\end{array}$ & 3.27 & 0.77 & 9 & 3.40 & 0.74 & 9 & 3.29 & 0.77 & 9 \\
\hline 11 & $\begin{array}{l}\text { Having } \\
\text { dedication to } \\
\text { the teaching } \\
\text { profession }\end{array}$ & 1.57 & 0.68 & 15 & 3.27 & 0.71 & 14 & 1.93 & 0.98 & 15 \\
\hline 12 & $\begin{array}{l}\text { Having } \\
\text { enthusiasm } \\
\text { teaching the } \\
\text { language }\end{array}$ & 3.34 & 0.78 & 8 & 3.37 & 0.67 & 10 & 3.35 & 0.76 & 13 \\
\hline 13 & $\begin{array}{l}\text { Having } \\
\text { up-to-date } \\
\text { information }\end{array}$ & 3.51 & 0.65 & 5 & 3.45 & 0.50 & 5 & 3.50 & 0.62 & 6 \\
\hline 14 & $\begin{array}{l}\text { Having strong } \\
\text { self-confidence }\end{array}$ & 3.53 & 0.73 & 4 & 3.52 & 0.75 & 3 & 3.53 & 0.73 & 3 \\
\hline 15 & $\begin{array}{l}\text { Being dynamic } \\
\text { and energetic }\end{array}$ & 3.22 & 0.83 & 10 & 3.50 & 0.55 & 4 & 3.28 & 0.79 & 10 \\
\hline 16 & $\begin{array}{l}\text { Accepting } \\
\text { constructive } \\
\text { criticism }\end{array}$ & 3.13 & 0.88 & 14 & 3.20 & 0.52 & 15 & 3.14 & 0.82 & 13 \\
\hline
\end{tabular}


It is clear from Table 3, that the means of students' responses of the personal traits criterions of an effective EFL teacher ranged from (3.57) to (1.40) and that the total mean of students' responses in this dimension is (3.13).

At the level of each item of this dimension, Table 3, reveals the following results:

- The highest rank goes to the items 9"Showing a good moral character", and 6, "maintaining a good teacher-student relationship" respectively, with a mean of (3.57) for both.

- The lowest rank goes to the items 11, "Having dedication to the teaching profession", and 7, "Treating students with respect" respectively, with a mean of (1.57) and (1.40) respectively.

Moreover, it can be seen from Table 3, that the means of teachers' responses of the personal traits criterions of an effective EFL teacher ranged from (3.62) to (3.00) and that the total mean of teachers' responses in this dimension is (3.39).

At the level of each item of this dimension, Table 3 reveals the following results:

- The highest rank goes to the items 9,"Showing a good moral character", and 7, "Treating students with respect" respectively, with a mean of (3.62) and (3.57) respectively.

- The lowest rank goes to the items 16, "Accepting constructive criticism", and 1, "Avoiding student favoritism" respectively, with a mean of (3.20) and (3.00) respectively.

Additionally, it is shown from Table 3, that the means of all participants' responses of the personal traits criterions of an effective EFL teacher ranged from (3.66) to (1.86) and that the total mean of all participants' responses in this dimension is (3.20).

At the level of each item of this dimension, Table 3, reveals the following results:

- The highest rank goes to the items 8,"Understanding of others", and 9, "Showing a good moral character" respectively, with a mean of (3.66) and (3.58) respectively.

- The lowest rank goes to the items 11, "Having dedication to the teaching profession", and 7, "Treating students with respect" respectively, with a mean of (1.93) and (1.86) respectively.

To sum it up, "showing a good moral character" is considered as the most dominant personal trait by both students and teachers. Whereas "maintaining a good teacher-student relationship" is ranked by students as the second dominant personal trait. This may be due to the fact that students are interested in their relationship with their teacher. It is apparent that students want to make a connection to their teachers; they want a positive relationship. Borg (2006) also suggested that the relationship between the EFL teacher and students is important because there is more communication between teacher and students in language teaching. Similar finding were reported in the studies of Al-Maqtri and Thabet (2013), and Celik, Arikan, and Caner (2013). Moreover, "treating students with respect" is rated by teachers as the second dominant personal trait. This result is supported by Chen and Lin (2009) and Shahini and Daftarifard (2011). They claim that respectful behavior towards students will bring about a stress free and friendly atmosphere which can greatly induce high levels of language learning.

\subsection{Results Concerning the Dominant Instructional Skills of Effective EFL Teachers}

To answer the study question "What are the dominant instructional skills of an effective teacher as perceived by Saudi EFL students and teachers at the intermediate level?", the mean scores, standard deviations and the rank of each criterion of the instructional skills were calculated in order to identify the most dominant skills as depicted in Table 4.

Table 4. Descriptive statistics and rank order of each criterion of the instructional skills of an effective EFL teacher

\begin{tabular}{|c|c|c|c|c|c|c|c|c|c|c|}
\hline \multirow[t]{2}{*}{ No } & \multirow[t]{2}{*}{ Item } & \multicolumn{3}{|c|}{ Students } & \multicolumn{3}{|c|}{ Teachers } & \multicolumn{3}{|c|}{ All Participants } \\
\hline & & Mean & S.D & Rank & Mean & S.D & Rank & Mean & S.D & Rank \\
\hline 17 & $\begin{array}{l}\text { Dividing class } \\
\text { time for the } \\
\text { different } \\
\text { language skills }\end{array}$ & 3.49 & 0.76 & 8 & 3.27 & 0.82 & 14 & 3.45 & 0.77 & 5 \\
\hline 18 & $\begin{array}{c}\text { Being } \\
\text { well-prepared } \\
\text { for the class }\end{array}$ & 3.49 & 0.65 & 7 & 3.50 & 0.75 & 3 & 3.49 & 0.67 & 4 \\
\hline
\end{tabular}


19 Being familiar

with the new

language

teaching

methods

20 Having a good

knowledge of the subject

matter

21 Checking

students' prior knowledge before providing new information

22 Planning to use a variety of instructional techniques

23 Planning lessons according to students individual differences

24 Displaying sensitivity to the needs of students when planning lessons

25 Linking lessons to real life situations

26 Setting lessons plans in which opportunities for discussions and interactions are created

27 Planning instructional materials effectively

28 Setting realistic goals for students to accomplish

29 Using a variety of activities during the lesson $\begin{array}{lllllllll}3.46 & 0.77 & 11 & 3.20 & 0.76 & 24 & 3.40 & 0.77 & 9\end{array}$

$\begin{array}{lllllllll}3.71 & 0.56 & 1 & 3.35 & 0.77 & 7 & 3.63 & 0.63 & 2\end{array}$

$\begin{array}{lllllllll}3.33 & 0.86 & 24 & 3.25 & 0.49 & 17 & 3.31 & 0.80 & 16\end{array}$

0.77

3.31

0.85

26

3.45

0.50

6

$3.34 \quad 0.79$

14

$3.45 \quad 0.7$

$0.76 \quad 13$

$$
13
$$

3.30

0.52

12

$3.42 \quad 0.72$

7

$3.41 \quad 0.7$

3.34

0.78

21

3.22

0.42

20

3.31

0.72

15 sing various types of

20

3.30

0.46

13

3.36

3.26

0.79

19

30

$3.26 \quad 0.9$

0.9131

$31 \quad 3.35$

$3.35 \quad 0.73$

0.738

$\begin{array}{lll}8 & 3.28 & 0.79\end{array}$
$3.37 \quad 0.83$ 


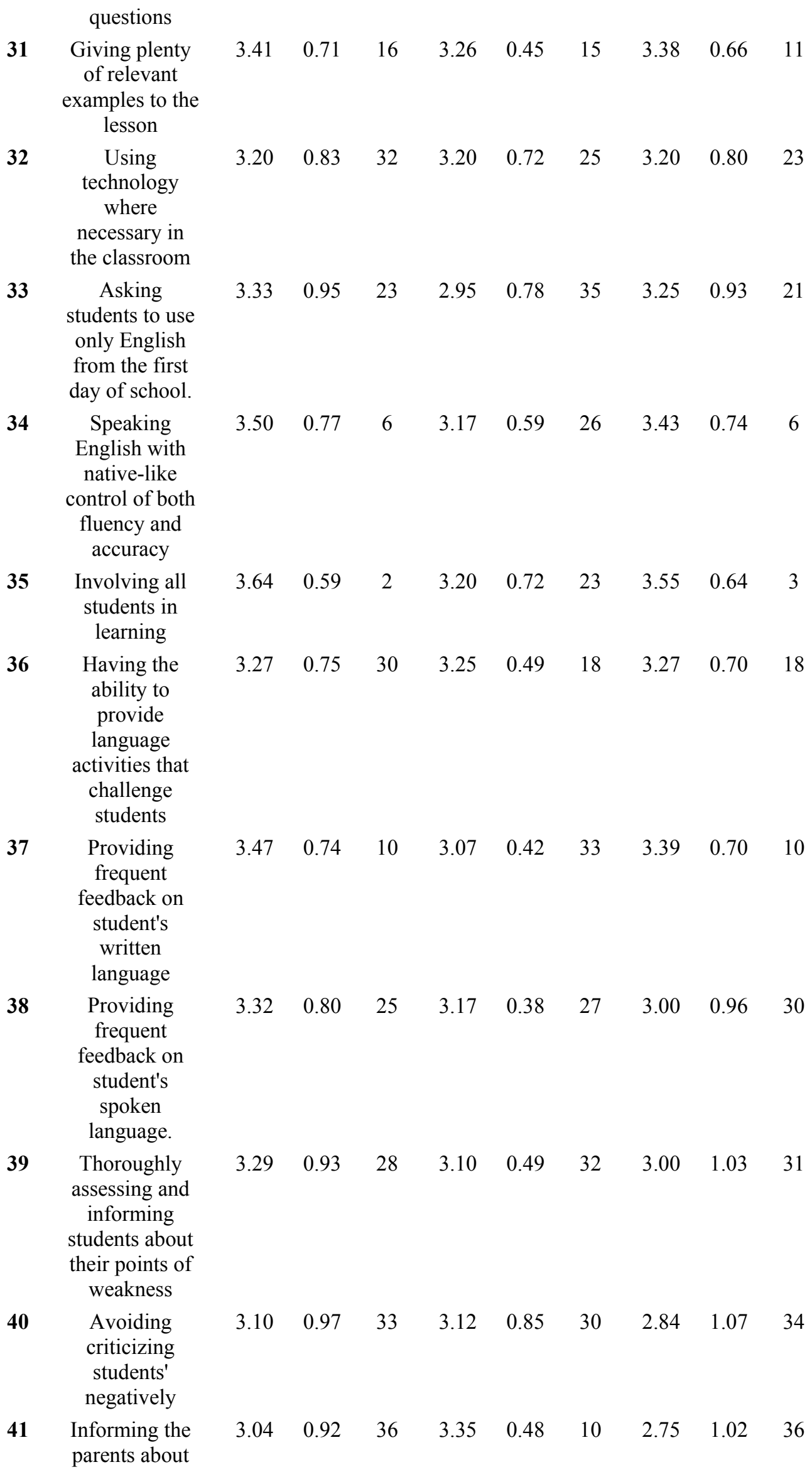

38 Providing frequent feedback on student's spoken language.

39 Thoroughly assessing and informing students about their points of weakness

$$
\begin{array}{lllllllll}
3.50 & 0.77 & 6 & 3.17 & 0.59 & 26 & 3.43 & 0.74 & 6
\end{array}
$$

$\begin{array}{lllllllll}3.64 & 0.59 & 2 & 3.20 & 0.72 & 23 & 3.55 & 0.64 & 3\end{array}$

$\begin{array}{lllllllll}3.27 & 0.75 & 30 & 3.25 & 0.49 & 18 & 3.27 & 0.70 & 18\end{array}$

$\begin{array}{lllllllll}3.47 & 0.74 & 10 & 3.07 & 0.42 & 33 & 3.39 & 0.70 & 10\end{array}$

$\begin{array}{llllllllll}\text { Avoiding } & 3.10 & 0.97 & 33 & 3.12 & 0.85 & 30 & 2.84 & 1.07 & 34\end{array}$

criticizing students' negatively

41 Informing the parents about 


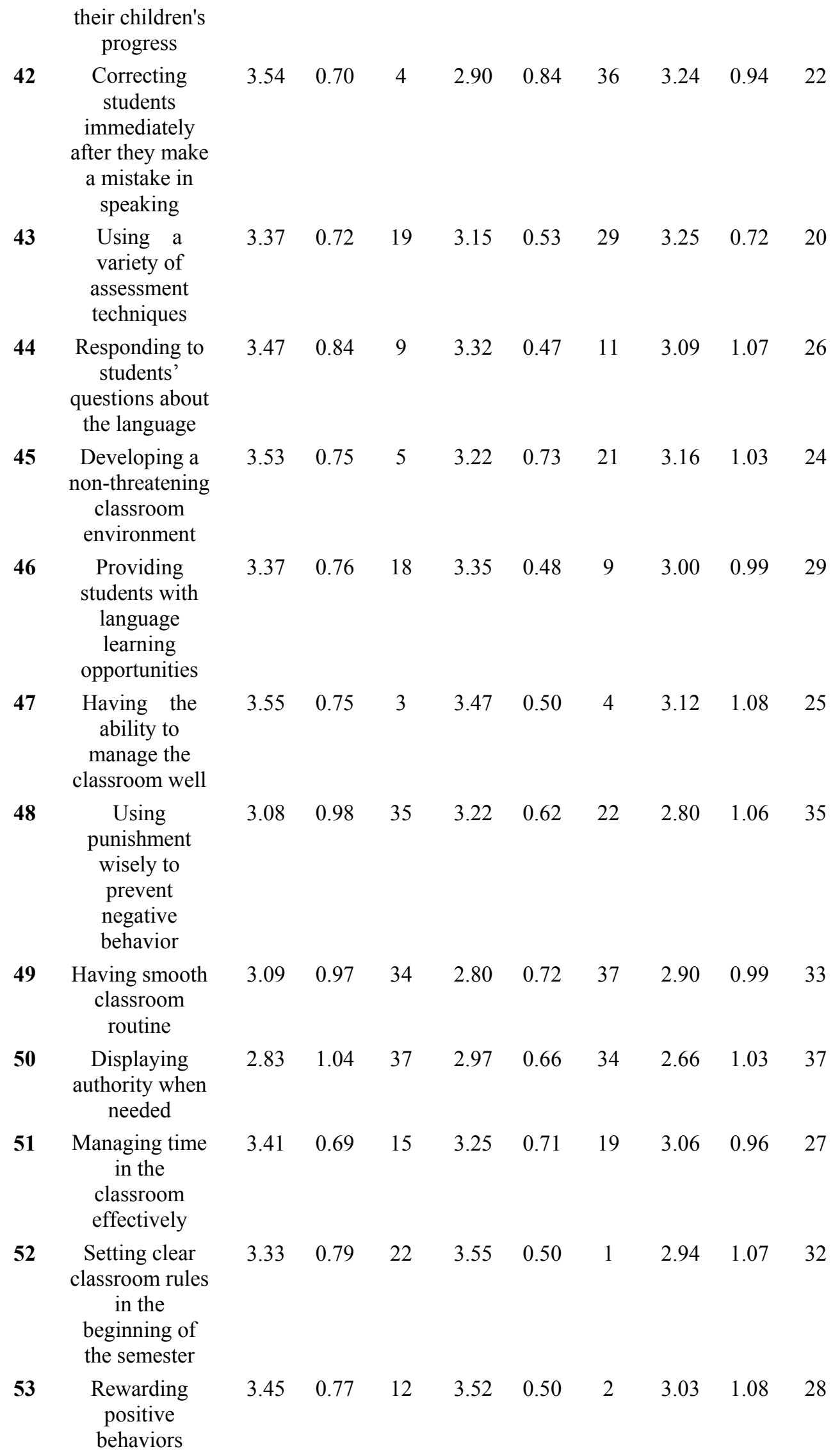


It is clear from Table 4 that the means of students' responses of the instructional skills criterions of an effective EFL teacher ranged from (3.71) to (2.83) and that the total mean of students' responses in this dimension is (3.35).

At the level of each item of this dimension, Table 4, reveals the following results:

- The highest rank goes to the items 20,"Having a good knowledge of the subject matter", and 35, "Involving all students in learning" respectively, with a mean of (3.71) and (3.64) respectively.

- The lowest rank goes to the items 41, "Informing the parents about their children's progress", and 7, "Displaying authority when needed" respectively, with a mean of (3.04) and (2.83) respectively.

Furthermore, it can be seen from Table 4, that the means of teachers' responses of the instructional skills criterions of an effective EFL teacher ranged from (3.55) to (2.80) and that the total mean of teachers' responses in this dimension is (3.24).

At the level of each item of this dimension, Table 4, reveals the following results:

- The highest rank goes to the items 52,"Setting clear classroom rules in the beginning of the semester", and 53, "Rewarding positive behaviors" respectively, with a mean of (3.55) and (3.52) respectively.

- The lowest rank goes to the items 42, "Correcting students immediately after they make a mistake in speaking",and 49, "Having smooth classroom routine" respectively, with a mean of (2.90) and (2.80) respectively.

Additionally, it is shown from Table 4 that the means of all participants' responses of the instructional skills criterions of an effective EFL teacher ranged from (3.69) to (2.66) and that the total mean of all participants' responses in this dimension is (3.22).

At the level of each item of this dimension, Table 4, reveals the following results:

- The highest rank goes to the items 22,"Planning to use a variety of instructional techniques", and 20, "Having a good knowledge of the subject matter" respectively, with a mean of (3.69) and (3.63) respectively.

- The lowest rank goes to the items 41, "Informing the parents about their children's progress", and 50, "Displaying authority when needed" respectively, with a mean of (2.75) and (2.66) respectively.

To sum it up, "having a good knowledge of the subject matter" is ranked by students as the most dominant instructional skill of effective EFL teachers. This result supports the ideas of Park and Lee (2006) and Chen (2012). "Involving all students in learning" is placed by students as the second dominant instructional skill. A possible explanation for this result might be that when students are involved in their own learning they will be excited and motivated to pay attention in class. Consequently, the teacher will also get excited because her/his students actually are paying attention.

Regarding the teachers' perceptions of the most dominant instructional skills, "setting clear classroom rules in the beginning of the semester" is placed at the top of the list mean, while the "having smooth classroom routine" is placed at the bottom of this list. These findings are inconsistent with the findings of McBer (2000) who asserts that effective EFL teachers use the minimum amount of classroom rules and more routines to preserve a relaxed, friendly and warm environment to enhance learning. He further states that this strategy provides students with maximum time to focus on tasks, and thus maximize the learning opportunity. Furthermore, Rewarding positive behaviors is ranked by teachers as the second dominant instructional skill.

\subsection{Results Concerning the study Hypothesis}

To test the hypothesis "there were no statistically significant differences at level 0.05 in the perceptions of Saudi EFL students and teachers with respect to the qualities of effective teachers", independent samples t-test was used and the results are illustrated in Table 5. 
Table 5. Independent samples t-test of the qualities of effective EFL teachers

\begin{tabular}{cccccccc}
\hline Dimension & Participants & $\boldsymbol{N}$ & Mean & $\begin{array}{c}\text { Std. } \\
\text { Deviation }\end{array}$ & $\boldsymbol{d f}$ & $\boldsymbol{t}$ & $\boldsymbol{P}$ \\
\hline Personal & Students & 150 & 3.13 & 0.36 & 188 & 3.780 & 0.000 \\
Traits & Teacher & 40 & 3.39 & 0.44 & & & \\
Instructional & Students & 150 & 3.35 & 0.39 & 188 & 1.993 & 0.50 \\
Skills & Teacher & 40 & 3.24 & 0.30 & & & \\
Total Mean & Students & 150 & 3.29 & 0.36 & 188 & 0.089 & 0.929 \\
& Teacher & 40 & 3.28 & 0.33 & & & \\
\hline
\end{tabular}

From Table 5 , it is clear that the $t$ value for the mean differences of personal traits of effective teachers between students and teachers is 3.78 and its corresponding $p$ value is $0.000<0.05$. Since the $p$ value is less than 0.05 , we can conclude that there is a statically significant difference between students and teachers regarding the personal traits of effective teachers. Hence the null hypothesis is rejected. Furthermore, an independent-samples t-test of the perceptions of students and teachers regarding the investigated personal traits of effective EFL teachers indicated that highly significant differences were found, $\mathrm{t}(188)=3.780, \rho=.000$. More specifically, scores were significantly lower for students $(\mathrm{M}=3.13, \mathrm{SD}=0.36)$ than for teachers $(\mathrm{M}=3.39, \mathrm{SD}=0.44)$.

Moreover, from Table 5, it is clear thatthe $\mathrm{t}$ value for the mean differences of instructional skills of effective teachers between students and teachers is 1.993 and its corresponding $p$ value is $0.050=0.05$. Since the $p$ value equals 0.05 , we can conclude that there is significant difference between students and teachers. Hence the null hypothesis is rejected. Moreover, the test revealed a statistically significant difference between students and teachers, $\mathrm{t}(188)=1.993, \rho=.050$. Students' $(\mathrm{M}=3.35, \mathrm{SD}=0.39)$ scores were significantly higher than teachers' $(\mathrm{M}=3.24, \mathrm{SD}=0.30)$.

Additionally, as it is shown in the Table 5 , the $t$ value for the mean differences of qualities of effective teachers between students and teachers is 0.089 and its corresponding $p$ value is $0.929>0.05$. Since the $p$ value is higher than 0.05 , we can conclude that there is no significant difference between students and teachers. Hence the null hypothesis is accepted. The results further indicated that there were no statistically significant differences, $\mathrm{t}(188)$ $=0.089, \rho=0.929$, between students $(\mathrm{M}=3.29, \mathrm{SD}=0.36)$ and teachers $(\mathrm{M}=3.28, \mathrm{SD}=0.33)$ perceptions regarding the investigated qualities of effective EFL teachers and that they both agreed with these qualities.

It can be indicated that the teachers who agreed with the personal traits of effective EFL teachers outnumbered the students who agreed. Teachers seem to value these traits more than students. It seems possible that teachers appreciate the significant role of the effective teachers' personal traits in creating an anxiety free classroom environment where students would feel comfortable to interact with peers and express their ideas freely.

Furthermore, the findings about the instructional skills reveal differences between students and teachers. Students place more importance on these skills more than teachers. A possible explanation for this result might be that students prefer teachers to be more conversant with instruction as this might help them understand things easily. Additionally, the teachers viewed an effective EFL teacher as a material presenter and content demonstrator, not as a manager of language learning situations. This leads to the traditional role of the teacher as a provider of information.

Additionally, differences are not found between students' and teachers' perceptions regarding the qualities of effective EFL teachers. Teachers seem to value the personal traits of effective EFL teachers more than students. Students considered the effective EFL teacher's instructional skills more important than the teachers. These finding are also consistent with the ideas of Khojastehmehr and Takrimi (2009) and Shishavan and Sadeghi (2009).

\section{Recommendations}

Based on the findings of the study, the following recommendations are made:

1. EFL teachers should do some self-reflection regarding their own qualities from the perceptions of the students to achieve effectiveness.

2. Knowing about what qualities the students like and dislike, EFL teachers should do some preparation and adjustment before going into the classroom. 
3. EFL teachers should give serious consideration to the views of their students and should encourage them to express their opinions and thoughts freely, to accept their criticism and to take their assessment as a method of self-improvement.

4. EFL teachers should receive in-service teacher training programs regularly at least once a year by professionals in the field of language planning curriculum and instruction.

\section{Suggestions for Future Studies}

Based on the findings of the current study, the following studies are suggested:

1. The perceptions of students and teachers toward the qualities of effective EFL teachers need to be investigated in other stages of education and conducted on male students and teachers.

2. Investigations are needed to make comparison in the perceptions of pre-service EFL teachers, administrators, students, and parents regarding the qualities of effective EFL teachers.

3. Researchers may be interested in a study to explore the relation of teacher qualities, including ratings of teacher quality, to classroom instructional variables and to students' language outcomes.

\section{References}

Al-Maqtri, M. \& Thabet, A. (2013). The qualities of the good English teacher as perceived by Saudi and Yemeni college students of English. Greener Journal of Educational Research, 3(2), 072-079. Retrieved November 7, 2013, from: http://www.gjournals.org

Anderson, W. (2004). Increasing teacher effectiveness. Paris: UNESCO, International Institute for Educational Planning.

Bell, T. (2005). Behaviors and attitudes of effective foreign language teachers: Results of a questionnaire study. Foreign Language Annals, 38(2), 259-270. https://doi.org/10.1111/j.1944-9720.2005.tb02490.x

Borg, S. (2006). The distinctive characteristics of foreign language teachers. Language Teaching Research, 10(1), 3-31. Retrieved November 2, 2013, from: http://www.education.leeds.ac.uk

Brown, V. (2009). Students' and teachers' perceptions of effective foreign language teaching: A comparison of ideals. The Modern Language Journal, 93(1), 46-60. https://doi.org/10.1111/j.1540-4781.2009.00827.x

Celik, S., Arikan, A. \& Caner, M. (2013). In the eyes of Turkish EFL learners: What makes an effective foreign language teacher. Porta Linguarum, 20, 287-297. Retrieved November 3, 2013, from: http://www.ugr.es

Chen, J. (2012). Favorable and unfavorable characteristics of EFL teachers perceived by university students of Thailand. International Journal of English Linguistics, 2(1), 213-219. https://doi.org/10.5539/ijel.v2n1p213

Chen, J. \& Lin, C. (2009). Exploring characteristics for effective EFL teachers from the perceptions of junior high school students in Tainan. STUT Journal of Humanities and Social Sciences, 2, 219- 249. Retrieved November 2, 2013, from: http://society.stust.edu

Gao, M. \& Liu, Q. (2013). Personality traits of effective teachers represented in the narratives of American and Chinese pre-service teachers: A cross-cultural comparison. International Journal of Humanities and Social Science, 3(2).

Hativa, N., Barak, R. \& Simhi, E. (2001). Exemplary university teachers: Knowledge and beliefs regarding effective teacher dimensions and strategies. Journal of Higher Education, 72(6), 699-729. Retrieved November 10, 2013, from: http://www.jstor.org

Jasman, A. (2003). Initial teacher education: Changing curriculum, pedagogies and assessment. Change: Transformations in education, 6(2), 1-22. Retrieved November 7, 2013, from: http://hdl.handle.net/2123/4498

Khodabakhshzadeh, H. \& Shirvan, M. (2011). Discovering Iranian EFL teachers' personality traits through their conceptions of effective teaching. Canadian Social Science, $7(4), \quad 21-33$. http://dx.doi.org/10.3968/j.css.1923669720110704.051

Khojastehmehr, R. \& Takrimi, A. (2009). Characteristics of effective teachers: Perceptions of the English teachers. Journal of Education \& Psychology, 3(2), 53-66. Retrieved November 12, 2014, from: http://www.sid.ir/En 
Lee, J. (2010). The uniqueness of EFL teachers: Perceptions of Japanese learners. TESOL Journal, 1(1), 23-48. https://doi.org/10.5054/tj.2010.214881

Liakopoulou, M. (2011). The professional competence of teachers: Which qualities, attitudes, skills and knowledge contribute to a teacher's effectiveness. International Journal of Humanities and Social Science, 1(21). Retrieved November 7, 2013, from: http://www.ijhssnet.com

Malikow, M. (2005). Effective teacher study. National Forum of Teacher Education-journal, 16(3). Retrieved November 10, 2013, from: http://www.nationalforum.com

McBer, H. (2000). Research into teacher effectiveness: A model of teacher effectiveness. UK: Crown.

Mullock, B. (2003). What makes a good teacher? The perceptions of postgraduate TESOL students. Prospect, 18(3), 3-24. Retrieved November 3, 2013, from: http://www.ameprc.mq.edu.au

Park, P. \& Lee, W. (2006). The characteristics of effective English teachers as perceived by high school teachers and students in Korea. Asia Pacific Education Review, 7(2), 236-248. Retrievedt Novembert 2, 2013, from: http://files.eric.ed.gov

Rubio, C. (2009). Effective teachers: Professional and personal skills. ENSAYOS, 24, 35-46.

Saafin, S. (2005). An investigation into Arab students' perceptions of effective EFL teachers at university level. Published dissertation, University of Exeter, UK.

Sadeghi, K. \& Babai, H. (2009). Becoming an effective EFL teacher: Living up to the expectations of L2 learners and teachers of English. Germany: VDM. https://doi.org/10.5539/elt.v2n4p130

Shahini, A. \& Daftarifard, P. (2011). Learners' beliefs of an effective teacher: A case of Iranian context. Broad Research in Artificial Intelligence and Neuroscience, 2(1), 29-37.

Shishavan, H. \& Sadeghi, K. (2009). Characteristics of an effective English language teacher as perceived by Iranian teachers and learners of English. English Language Teaching, 2(4), Retrieved February 12, 2014, from: www.ccsenet.org/journal

Slate, J. (2009). Hispanic college students' perceptions of characteristics of effective elementary school teachers: A multi-stage mixed analysis. Journal of Educational Research \& Policy Studies, 9(1), 1-24.

Stronge, H. (2004). Qualities of effective teacher facilitator's guide. Alexandria, VA: Association for Supervision and Curriculum Development.

Stronge, J. (2007). Qualities of effective teachers. 2nd edit. USA: ASCD publication.

Wang, J., Gibson, M. \& Slate, R. (2007). Effective teachers as viewed by students at a two year college: A multistage mixed analysis. Issues in Educational research, 17(2), 272-295.

Wheeler, V. \& Mcleod, L. (2002). Expanding our teaching effectiveness: Understanding our responses to "in-the- moment" classroom events. Journal of Management Education, 26, 693-1006.tRetrievedtNovembert4,t2013,tfrom:http://jme.sagepub.com

Williams, M. \& Burden, R. (1997). Psychology for language teachers: A social constructivist approach. In Ganjabi, M. (Ed). Effective foreign language teaching: A matter of Iranian students' and teachers' beliefs. 4(2), 46. https://doi.org/10.5539/elt.v4n2p46

Witcher, A. (2003). Students' perceptions of characteristics of effective college teachers. Published master's thesis, University of South Florida, USA.

\section{Copyrights}

Copyright for this article is retained by the author(s), with first publication rights granted to the journal.

This is an open-access article distributed under the terms and conditions of the Creative Commons Attribution license (http://creativecommons.org/licenses/by/4.0/). 